\title{
The Effect Of A Variable Percentage Of Limestone Filler On Some Mechanical Properties Of Self-Compacting Concrete
}

\author{
Ashtar S. Al-Luhybi \\ Assistant Lecturer \\ University of Mosul/College of Engineering/Civil Engg. Dept.
}

\section{Abstract}

The first aim of this experimental program is to produce and evaluate Self-Consolidating Concrete (SCC); the second aim is to replace part of cement by predetermined percentages of limestone powder $\mathrm{CaCo}_{3}$ (LSP) to find out the effect of a variable percentage of LSP on some mechanical properties of SCC. The study also takes into account the difference between using the LSP as a replacement or as an additive of cement to the mix. Six concrete mixes were prepared. The first one was without LSP $(0 \%)$, second, third and fourth ones contained LSP as percentage replacement of cement in the order of $20,30,40 \%$ respectively, fifth and sixth mixes contained $20,30 \%$ LSP but as an additive to the cement. Results showed that using LSP as replacement of cement led to the production of SCC. Using LSP as replacement also led to economical advantages due to the decrease in plasticizer content, with no noticeable differences in mechanical properties of SCC, but causing a fluidity increase of SCC when using LSP as an additive.

Key words: Concrete mechanical Strength, Limestone Filler, Self-Compacting Concrete.

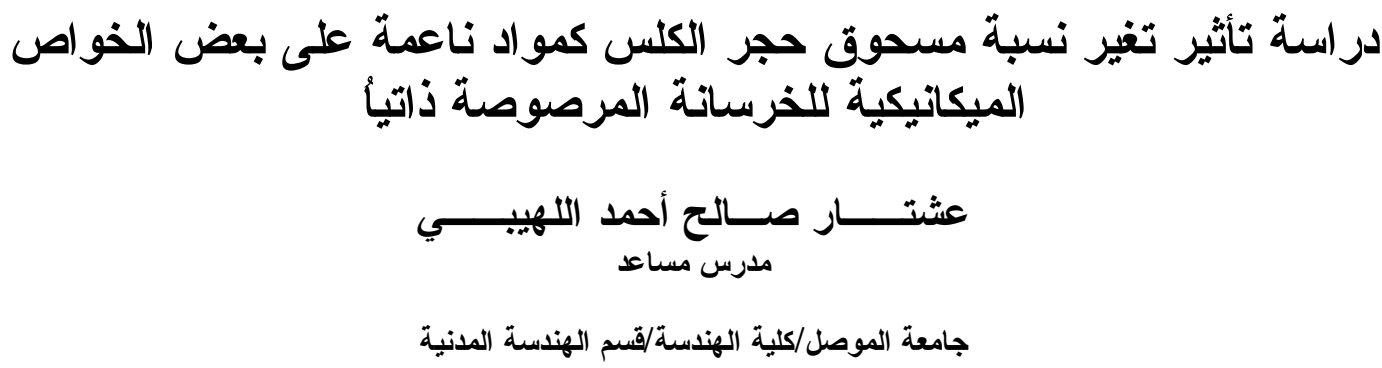

الخلاصة

ان الهذف الاول من البرنامج العملي لهذا البحث هو الحصول على خرسانة مرصوصة ذاتيا، اما الهدف الثاني من

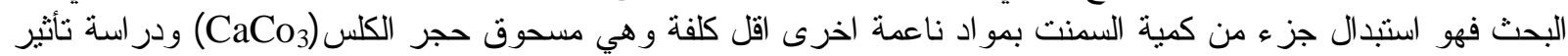

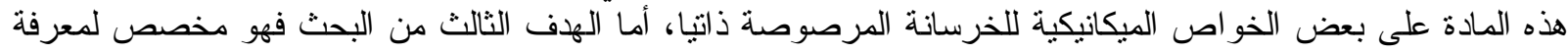

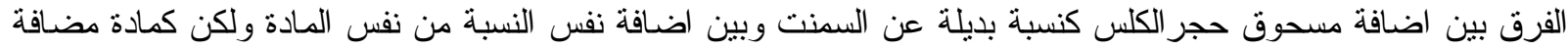

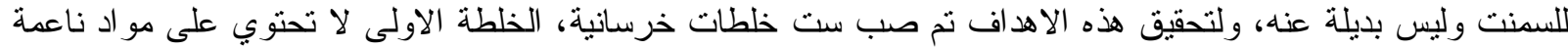

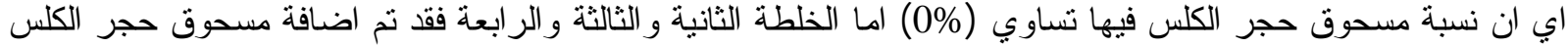

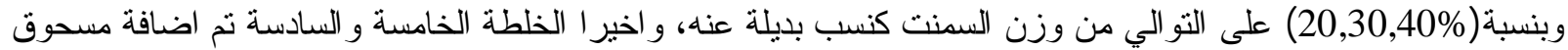

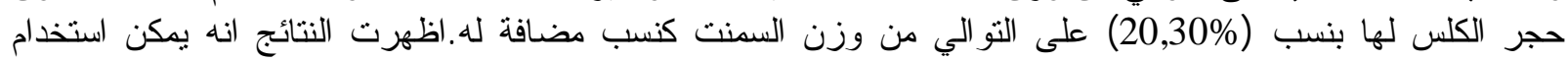

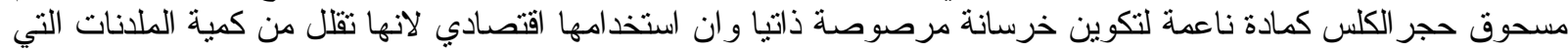

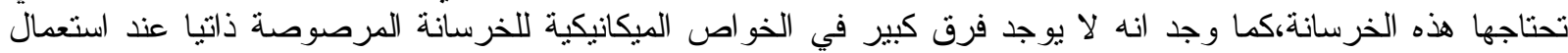
مسحوق حجر الكلس كبديل عن السمنت او كمادة مضافة عدا فيانة ان اضافة مسحوق حجر الكلس كمو اد مضافة يعمل على دئل زيادة سيولة الخرسانة. 


\begin{tabular}{llll} 
Al-Rafidain Engineering & Vol.17 & No.5 & October 2009 \\
\hline
\end{tabular}

\section{Introduction}

Self consolidating concrete (SCC) is defined as "a highly flowable, yet stable concrete that can spread readily into place and fill the formwork without any mechanical consolidation and without undergoing any significant separation"[1].

The concept of self consolidating concrete was proposed in 1986[2], but the prototype was first developed in 1988 in Japan [3].

Precast, prestressed bridge elements, such as AASHTO Type III girders, have congested reinforcement and tight dimensional geometry, and therefore can benefit from the use of SCC.

SCC has been claimed to offer many advantages for the precast, prestressed industry including elimination of noise and problems related to concrete vibration, lower labour cost per member, and faster casting, thereby increasing productivity.

Due to the low water-cement ratio, SCC should have improved durability and strength. With regard to its composition, SCC consists of the same components as conventionally vibrated concrete, which are cement, aggregates, and water, with the addition of chemical and mineral admixtures in different proportions. Usually, the chemical admixtures used are high-range water reducers (superplasticizers) and viscosity-modifying agents, which change the rheological properties of concrete.

Mineral admixtures are used as an extra fine material, besides cement, and in some cases, they are used as partial replacement of cement. In SCC cement content may be partially replaced with, fly ash, slag cement, limestone filler and silica fume, to improve the flowing and strengthening characteristics of the concrete.

\section{Research Scope}

The scope of this research is to find out the effect of a variable percentage of limestone filler on some mechanical properties of SCC.

\section{Experimental Program}

This research was conducted to find some properties of SCC such as splitting tensile strength, compressive strength, and flexural strength.

The experimental work consists of three sets of different specimens: cubes, cylinders and beams, amounting to twelve cubes, three cylinders and three beams for each mix, the watercement ratio was 0.33 .

The added ratios of limestone powder as a replacement of cement were 20,30 , and $40 \%$ by weight of cement with a reference mix having no limestone powder(zero\%), making the number of tried mixes for this case four(see table 8) then two ratios of limestone powder $(20 \& 30 \%)$ were used as an additive material(not as a replacement), making the number of tried mixes in this other case, two.

The size of all the cast cubes were $4 \times 4$ inches $(101.6 \times 101.6 \mathrm{~mm})$, cylinders were 4 inches $(101.6 \mathrm{~mm})$ in diameter and 8 inches $(203.2 \mathrm{~mm})$ in length and beams of $(4 \times 4)$ inches in cross section and $19.6 \mathrm{in}(500 \mathrm{~mm})$ in length, all beams were tested in a two point load manner, the total number of cast specimens was 102.

Slump flow, L-Box and V-Funnel tests were carried out in order to evaluate the filling ability and the self-compactability of the concrete. 
Al-Luhybi : The Effect Of A Variable Percentage Of Limestone Filler On Some

\section{Materials:}

All materials used throughout this research were locally available. They included cement, water, fine aggregate, coarse aggregate, limestone filler, and a superplasticizer.

Cement: The type of cement used was Ordinary Portland Cement, produced in accordance with Iraqi Specification (IQS. No.5,1985)[4]. The physical and chemical properties are given in Tables (1) and (2) respectively.

Fine aggregate: Medium sand in accordance with British Standards (B.S.) 882:1992[5] was used in this investigation. Its main properties are listed in Table (3), Figure (1) shows the particles size distribution.

Coarse aggregate: Coarse aggregate used was normal river gravel (irregular almost rounded maximum aggregate size $(10 \mathrm{~mm})$ in accordance with B.S 882(1992) . [5]Its physical properties are given in Table (4), while its sieve analysis and grading are given in Figure (2).

Table (1): Chemical composition of the O.P.C.

\begin{tabular}{|c|c|c|}
\hline Property & Test result (Percentage) & Standard IQS, No.5 \\
\hline \multicolumn{3}{|l|}{ 1. Oxide composition: } \\
\hline Alumina, $\mathrm{Al}_{2} \mathrm{O}_{3}$ & 4.7 & \\
\hline Silica, $\mathrm{SiO}_{2}$ & 21.5 & \\
\hline Ferric Oxide, $\mathrm{Fe}_{2} \mathrm{O}_{3}$ & 2.41 & \\
\hline Lime, $\mathrm{CaO}$ & 62.86 & \\
\hline Sulphuric Anhydride, $\mathrm{SO}_{3}$ & 3.02 & Max. 3 \\
\hline Magnesia, $\mathrm{MgO}$ & 2.25 & Max. 4 \\
\hline \multicolumn{3}{|l|}{ 2.Compound composition: } \\
\hline $\mathrm{C}_{3} \mathrm{~A}$ & 8.4 & \\
\hline $\mathrm{C}_{2} \mathrm{~S}$ & 27.18 & \\
\hline $\mathrm{C}_{3} \mathrm{~S}$ & 46.14 & \\
\hline $\mathrm{C}_{4} \mathrm{AF}$ & 7.3 & \\
\hline
\end{tabular}

Table (2): Physical properties of the O.P.C.

\begin{tabular}{|c|c|c|}
\hline Property & Test result & Standard \\
\hline Fineness(Residue on sieve No. 170) & $9 \%$ & Max. 10\% \\
\hline Specific surface "Blaine" & $3358.5(\mathrm{~cm} 2 / \mathrm{gm})$ & Min. 2250 \\
\hline Initial setting time & $150(\mathrm{~min})$. & $\geq 45(\mathrm{~min})$. \\
\hline Final setting time & $215(\mathrm{~min})$. & $\leq 600$ (min.) \\
\hline Specific gravity & 3.14 & \\
\hline $\begin{array}{c}\text { Compressive strength } \\
\text { 70.7mm cubes }\end{array}$ & & \\
\hline at 3 days & $21.4(\mathrm{MPa})$ & $\geq 16.0(\mathrm{MPa})$ \\
\hline at 7 days & $36(\mathrm{MPa})$ & $\geq 24.0(\mathrm{MPa})$ \\
\hline
\end{tabular}


Table (3): Relative properties of fine aggregate

\begin{tabular}{|c|c|c|c|c|c|c|}
\hline $\begin{array}{c}\text { Type of } \\
\text { fine } \\
\text { aggregate }\end{array}$ & Color & \multicolumn{2}{|c|}{$\begin{array}{c}\text { Specific } \\
\text { Gravity }\end{array}$} & $\begin{array}{c}\text { Absorption } \\
\%\end{array}$ & $\begin{array}{c}\text { Compact } \\
\text { unit weight } \\
(\mathrm{kg} / \mathrm{m} 3)\end{array}$ & $\begin{array}{c}\text { Loose unit } \\
\text { weight } \\
(\mathrm{kg} / \mathrm{m} 3)\end{array}$ \\
\hline $\begin{array}{c}\text { Medium } \\
\text { sand }\end{array}$ & \multirow{2}{*}{ Brown } & $\begin{array}{c}\text { Oven } \\
\text { dry basis }\end{array}$ & $\begin{array}{c}\text { S.S.D } \\
\text { basis }\end{array}$ & \multirow{2}{*}{1.0} & 1939 & 1883 \\
\cline { 3 - 4 } & 2.38 & 2.36 & & & \multirow{2}{*}{} \\
\hline
\end{tabular}

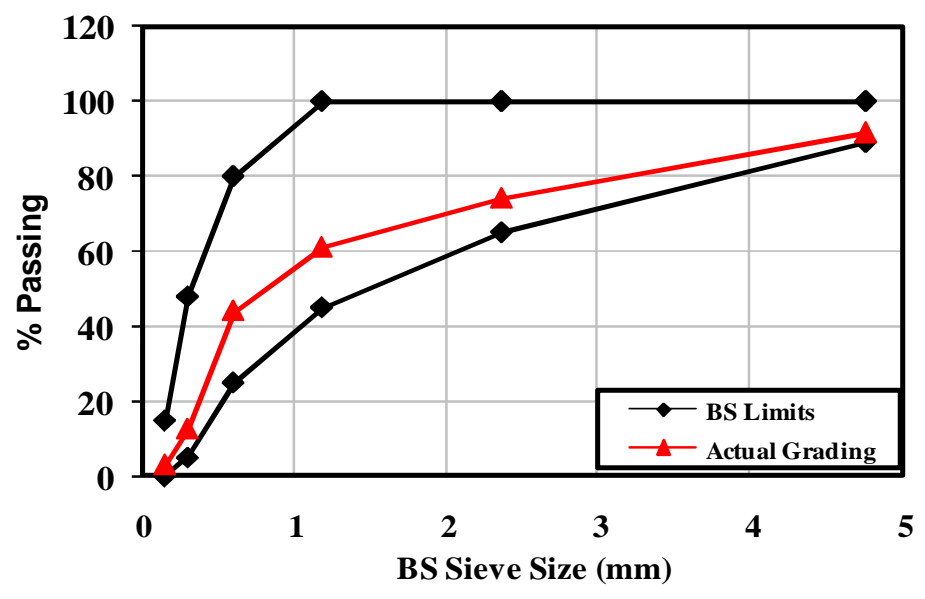

Figure (1): Grading curve for fine aggregate

Table (4): Relative properties of coarse aggregate

\begin{tabular}{|c|c|c|c|c|c|}
\hline $\begin{array}{c}\text { Type of } \\
\text { coarse } \\
\text { aggregate }\end{array}$ & $\begin{array}{c}\text { Maximum } \\
\text { aggregate } \\
\text { size }(\mathbf{m m})\end{array}$ & $\begin{array}{c}\text { Specific } \\
\text { Gravity S.S.D }\end{array}$ & Absorption\% & $\begin{array}{c}\text { Compact unit } \\
\text { weight } \\
(\mathbf{K g} / \mathbf{m 3})\end{array}$ & $\begin{array}{c}\text { Loose unit } \\
\text { weight } \\
(\mathbf{K g} / \mathbf{m 3})\end{array}$ \\
\hline $\begin{array}{c}\text { Rounded } \\
\text { gravel }\end{array}$ & 10 & 2.7 & 0.5 & 1742 & 1656 \\
\hline
\end{tabular}

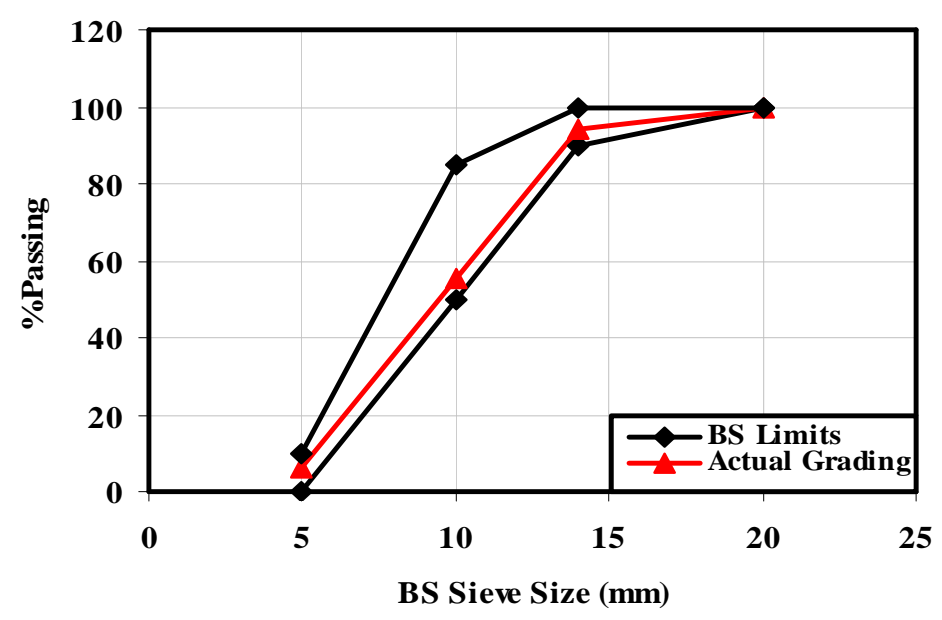

Figure (2): Grading curve for coarse aggregate 
Water: Ordinary drinking (tap) water was used for all concrete mixes.

Limestone Powder: Limestone powder $\left(\mathrm{CaCo}_{3}\right)$ was used as a filler material, the particles passing from sieve No. $100(0.150 \mathrm{~mm})$, in the present research three ratios of limestone powder are used 20, 30, and 40\%.

Chemical Admixture: Sikament-NN a high range water reducing (HRWR) was used in this work to get the necessary workability, stability and flowability. The main properties as recommended from factory are shown in Table (5).

Table (5): The Properties of HRWR

\begin{tabular}{|c|l|}
\hline Type & Naphthalene formaldehyde sulphonate \\
\hline Color & Dark brown \\
\hline Density & $1.2 \mathrm{~kg} / \mathrm{L}$ \\
\hline Dosage & $\begin{array}{l}\text { 0.8-3\% by weight of cement depending } \\
\text { on desired workability and strength }\end{array}$ \\
\hline
\end{tabular}

\section{Mix Proportion:}

The initial outcome of an experimental program aimed at producing and evaluating SCC made with high-volumes of limestone powder (LSP). Three SCC mixtures were investigated in this study. The tested mixtures were proportioned with the same initial slump flow consistency of $650 \pm 15 \mathrm{~mm}$. The content of the cementitious materials was maintained constant at $(450 \mathrm{~kg} / \mathrm{m} 3)$, while the water/ cementitious material ratio is constant at 0.33 . The self-compacting mixtures had a cement replacement(of limestone filler) at (20,30, and 40\%), for comparison purposes of the three batches, one of them made with Portland cement only and it had a similar slump flow, and the other two batches had ratios of added limestone powder of $20,30 \%$.

Tests were carried out on all mixes to find out the effect of a variable percentage of limestone powder on some mechanical properties of SCC. The proportions of the concrete mixtures are summarized in Table (6). For all the mixtures, the coarse and fine aggregates weights were taken at room dry condition.

Table (6): Proportions of the concrete mixes

\begin{tabular}{|c|c|c|c|c|c|c|c|c|}
\hline \multirow[t]{2}{*}{$\begin{array}{l}\text { Mix } \\
\text { No. }\end{array}$} & \multirow{2}{*}{$\frac{\mathrm{W}}{\mathrm{C}+\mathrm{LSP}}$} & \multirow[t]{2}{*}{$\begin{array}{l}\text { Water } \\
\mathrm{kg} / \mathrm{m}^{3}\end{array}$} & \multirow{2}{*}{$\begin{array}{l}\text { Cement } \\
\mathrm{kg} / \mathrm{m}^{3} \\
\text { O.P.C }\end{array}$} & \multicolumn{2}{|c|}{$\begin{array}{c}\text { Limestone } \\
\text { powder }\end{array}$} & \multirow{2}{*}{$\begin{array}{c}\text { Fine } \\
\text { agg. } \\
\mathrm{kg} / \mathrm{m}^{3}\end{array}$} & \multirow{2}{*}{$\begin{array}{c}\text { Coarse } \\
\text { agg. } \\
\mathbf{k g} / \mathbf{m}^{3}\end{array}$} & \multirow[t]{2}{*}{$\begin{array}{c}\text { SuperPlasticizer } \\
\%\end{array}$} \\
\hline & & & & $\%$ & $\mathrm{~kg} / \mathrm{m}^{3}$ & & & \\
\hline \multicolumn{9}{|c|}{ ORDINARY PORTLAND CEMENT } \\
\hline 1 & $\mathbf{0 . 3 3}$ & 149 & 450 & $\mathbf{0}$ & $\mathbf{0}$ & 756 & 743 & 1.75 \\
\hline 2 & $\mathbf{0 . 3 3}$ & 149 & 360 & 20 & 90 & 756 & 743 & 1.6 \\
\hline 3 & $\mathbf{0 . 3 3}$ & 149 & 315 & 30 & 135 & 756 & 743 & 1.625 \\
\hline 4 & $\mathbf{0 . 3 3}$ & 149 & 270 & 40 & 180 & 756 & 743 & 1.63 \\
\hline
\end{tabular}

There is no single test that can adequately measure the filling, passing and segregation also there were no standardized test methods or equipments adopted by ASTM. Below is a list of test methods for workability properties of SCC that had been employed previously. These equipments and Test methods have been employed by many researchers and agencies to investigate SCC rheology with good success. It is further expanded these equipments will be standardized without serious dimensional alterations [6]. 


\section{$\begin{array}{llll}\text { Al-Rafidain Engineering } & \text { Vol.17 } & \text { No.5 } & \text { October } 2009\end{array}$}

Slump-flow and $\mathrm{T}_{50}$ time for $\mathrm{SCC}$ :

The slump-flow and $\mathrm{T}_{50}$ time is a test to assess the flowability and the flow rate of selfcompacting concrete in the absence of obstructions.

\section{Procedure}

The equipment consists of one slump cone and one flow base plate made of a flat plate with a plane area on which concrete can be placed. The plate should have a flat, smooth and nonabsorbent surface with a minimum thickness of $2 \mathrm{~mm}$. The surface shall not be readily attacked by cement paste or be liable to rusting. The construction of the plate shall be such as to prevent distortion. The centre of the plate shall be scribed with a cross, the lines of which run parallel to the edges of the plate and with circles of $200 \mathrm{~mm}$ diameter and $500 \mathrm{~mm}$ diameter having their centers coincident with the centre point of the plate, see Figure(3).

The slump cone is filled with concrete while pressing the slump cone to the table. Next, the slump cone is lifted vertically and time measurement is started. Time for the concrete diameter to reach $500 \mathrm{~mm}\left(\mathrm{~T}_{50}\right)$ is recorded. When the concrete stops flowing, the final diameter $\left(d_{1}\right)$ of concrete is measured. Then measuring the diameter of the flow spreads at right angles to $d_{1}$ recorded as $d_{2}$. The slump-flow is the mean of $d_{1}$ and $d_{2}$ expressed to the nearest $10 \mathrm{~mm}$. The $\mathrm{T}_{50}$ time is reported to the nearest $0.1 \mathrm{~s}$ [7]. The concrete spread for segregation is checked. The cement paste/mortar may segregate from the coarse aggregate to give a ring of paste/mortar extending several millimeters beyond the coarse aggregate. Segregated coarse aggregate may also be observed in the central area.

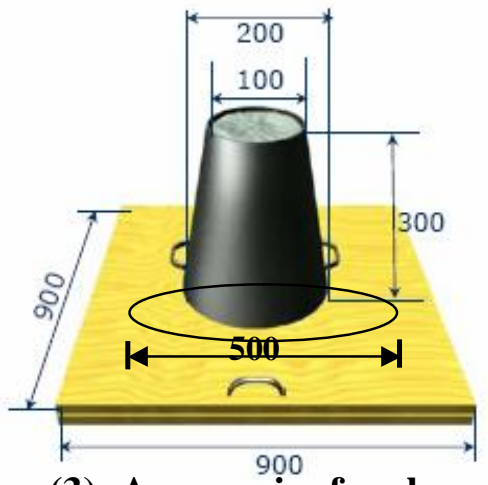

Figure (3): Accessories for slump flow test

V-funnel test: The V-funnel test is used to assess the viscosity and filling ability of SCC. The equipment consists of v-shaped as shown in Figure (4). The v-funnel is filled up to its upper level with concrete. After the concrete rests one minute in the v-funnel, the gate is opened. Time for concrete to flow out of the v-funnel (Flow-time) is recorded. The concrete is observed while it flows out and any blocking leading to total stoppage of flow or temporary stops is noted.
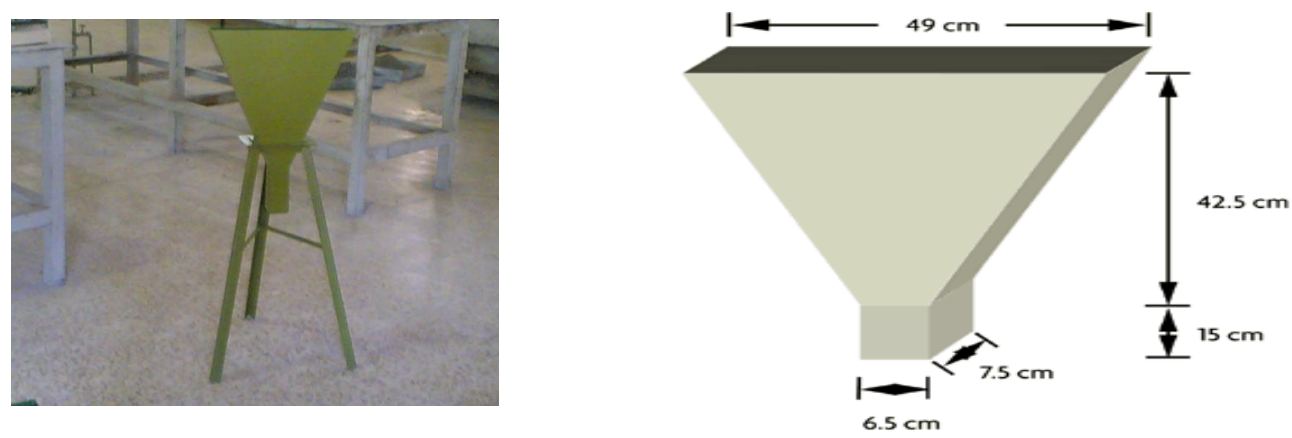

Figure (4): V-funnel apparatus 
L-Box test: The principles of the L-shaped box are shown in Figure (5). With the L-shaped box, it is possible to measure different properties, such as flowability, blocking and segregation. The vertical part of the box, with the extra adapter mounted, is filled with concrete. After the concrete has rested in the vertical part for one minute, the sliding gate is lifted. The concrete will now flow out of the vertical part into the horizontal part of the L-box.

On its way, it has to pass the layer of reinforcement. After the sliding gate is removed, the time for the concrete front to reach $(200 \mathrm{~mm})$ marking $\left(\mathrm{T}_{20}\right)$, and the time for the concrete front to reach $(400 \mathrm{~mm})$ marking $\left(\mathrm{T}_{40}\right)$ are recorded. When the concrete has stopped, the distance $\mathrm{H}_{1}$ and $\mathrm{H}_{2}$ at $(200 \mathrm{~mm})$ and $(400 \mathrm{~mm})$ mark are measured. Acceptable values of the so-called blocking ratio, $\mathrm{H}_{1} / \mathrm{H}_{2}$, can be $0.8-1.0[8]$. Both blocking stability can be detected visually. If the concrete builds a plateau behind the reinforcement layer, the concrete has either blocked or segregated. Blocking usually displays itself by coarse aggregates gathered between the reinforcing bars.
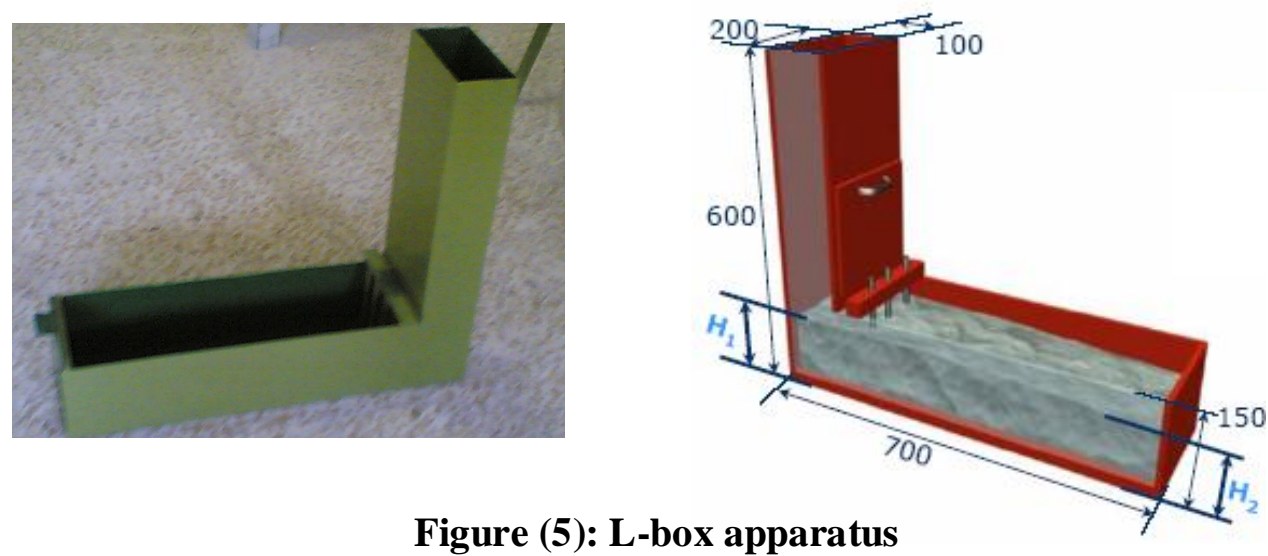

Figure (5): L-box apparatus

\section{Testing specimens:}

All concrete specimens have been cast and cured according to ASTM C192-95[9], and ASTM C496-96[10].

The moulds were oiled properly for easy demolding. Since this is a SCC, the concrete will flow under its own weight; therefore, the molds were not vibrated. After casting and finishing, the specimens were covered with plastic sheet to avoid loss of water due to evaporation. The specimens were demolded after 24 hours of casting and then they were transferred to a curing tank placed at laboratory temperature. The specimens were cured in the water tank for 28 days. 


\section{Results and Discussion}

\section{Compressive Strength:}

Results of fresh self-compacting and strengths tests conducted on four mixes are presented in Table (7)

Table (7): Results of fresh and hardened self-compacting concrete

\begin{tabular}{|c|c|c|c|c|c|c|c|c|c|c|}
\hline \multirow{2}{*}{ Mix } & \multicolumn{4}{|c|}{$\begin{array}{c}\text { Fresh Self-Compacting } \\
\text { properties }\end{array}$} & \multicolumn{4}{|c|}{$\begin{array}{c}\text { Compressive } \\
\text { Strength(MPa) } \\
\text { At indicated "age" days }\end{array}$} & \multirow{2}{*}{$\begin{array}{c}\text { Splitting } \\
\text { Strength } \\
\text { (MPa) at } \\
28 \\
\text { days }\end{array}$} & \multirow{2}{*}{$\begin{array}{c}\text { Flexural } \\
\text { Strength } \\
\text { (MPa) at } \\
28 \\
\text { days }\end{array}$} \\
\hline & $\begin{array}{l}\text { Flow } \\
\text { table* } \\
(\mathbf{m m})\end{array}$ & $\begin{array}{l}\text { T50 } \\
* * \\
(\sec )\end{array}$ & $\begin{array}{c}\text { V- } \\
\text { Funnel } \\
* * * * \\
(\text { sec })\end{array}$ & $\begin{array}{c}\text { L- } \\
\text { Box } \\
* * * *\end{array}$ & 3 & 7 & 28 & 56 & & \\
\hline $\begin{array}{l}\text { Mix1 } \\
(0 \%)\end{array}$ & 640 & 3.30 & 7.78 & 0.84 & 26.2 & 36.65 & 44.6 & 56.4 & 4.995 & 5.066 \\
\hline $\begin{array}{l}\text { Mix2 } \\
(20 \%)\end{array}$ & 660 & 3.38 & 9.81 & 0.88 & 18.2 & 29.4 & 40.7 & 53.3 & 3.667 & 3.67 \\
\hline $\begin{array}{c}\operatorname{Mix3} \\
(\mathbf{3 0 \%})\end{array}$ & 640 & 3.67 & 6.4 & 0.82 & 16.5 & 25.35 & 30.4 & 38 & 3.43 & 3.2 \\
\hline $\begin{array}{c}\text { Mix4 } \\
(40 \%)\end{array}$ & 650 & 3.67 & 11 & 0.9 & 14.8 & 20.26 & 28.5 & 37 & 2.809 & 2.75 \\
\hline
\end{tabular}

*Flow table value should be in the range of 650 to $800 \mathrm{~mm}$ [8].

$* *$ T50 value should be in the range of 3 to $5 \mathrm{sec}$ [8].

$* * * \mathrm{~V}$-funnel value should be in the range of 6 to $12 \mathrm{sec}$ [8].

$* * * *$ L-box value should be in the range of 0.8 to 1 [8].

The values of compressive strength of each mix at different curing ages, as presented in Table (7), were plotted as shown in Figure (7) to show the progress of compressive strength with curing period. Like traditionally consolidated concrete, SCC also continues to gain strength with curing time. The 28-day compressive strength of SCC is approximately $20-40 \%$ higher than the 7-day strength.

The highest 28-day compressive strength of $40.7 \mathrm{MPa}$ was achieved in mix2 and the lowest value of $28.55 \mathrm{MPa}$ was noted in mix4. As seen from Table (7) the variations in compressive strength for mix 1 and mix 2 are not obvious, but when the percentage of limestone filler increased the compressive strength decreased to reach $28.55 \mathrm{MPa}$ at $40 \%$. Generally speaking the effect of added limestone on the compression strength is noticeable from figure (7) i.e. the addition causing a reduction in the compression strength as compared to the reference mix at all the percentages tried. Fig (8) shows the relation between percentage of LSP and compressive strength at 28 days. 


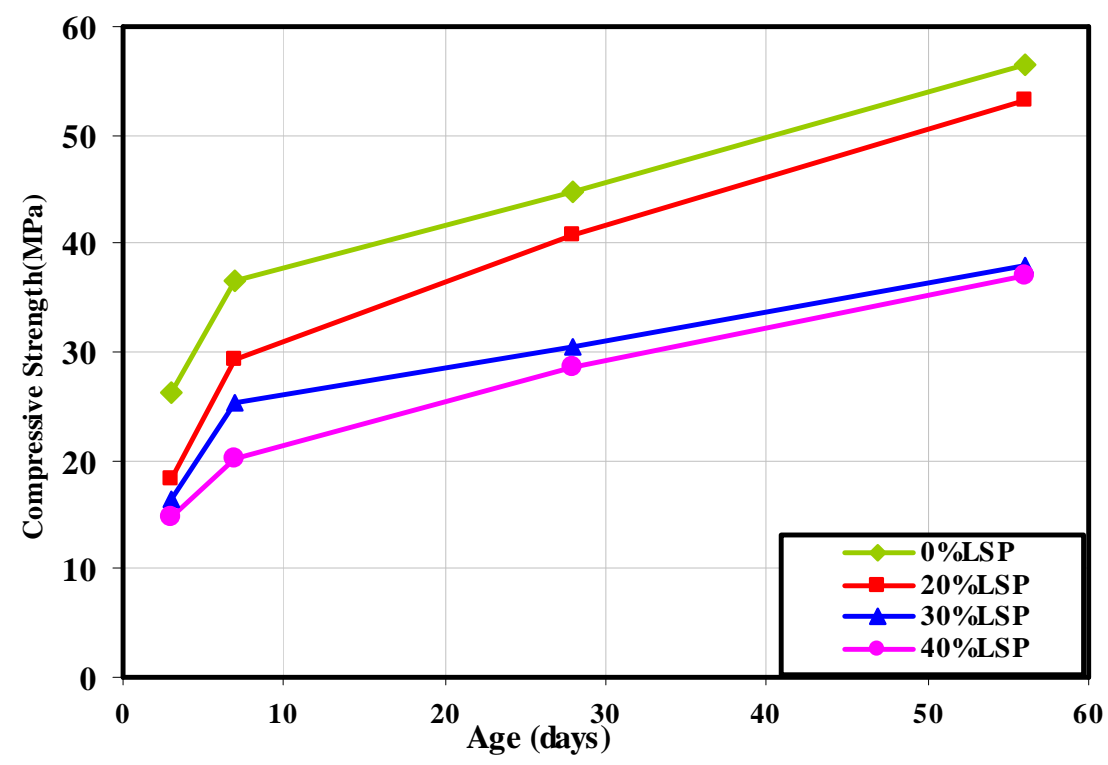

Figure (7): Compressive Strength of Mixes with curing time

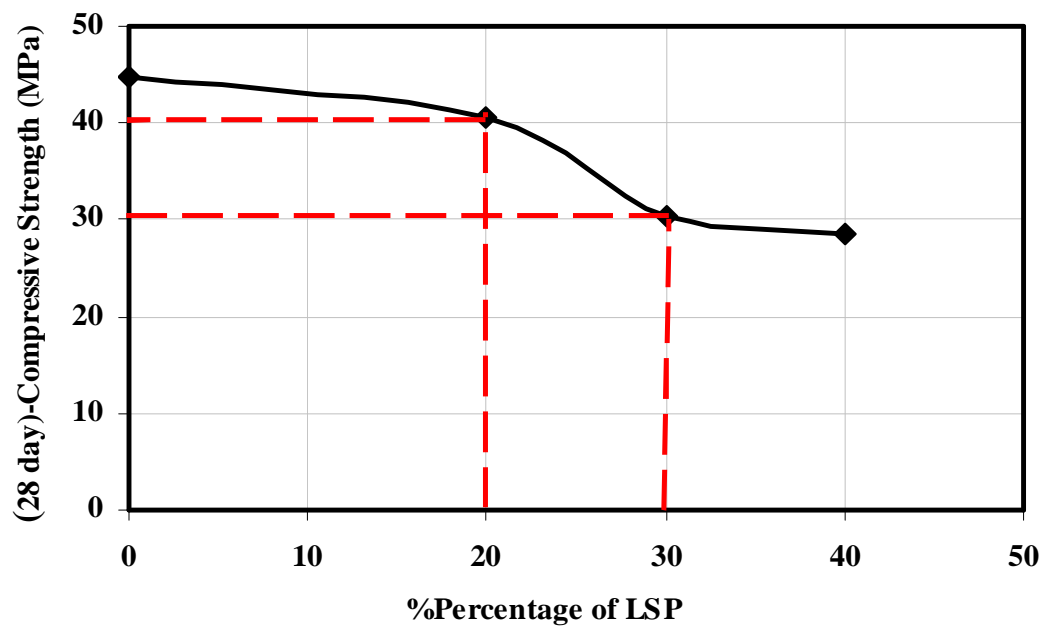

Figure (8): Relation between Percentage of LSP and Compressive Strength at 28 day

As observed from Table (7), all the mixes satisfied the self-compactibility criteria. By visual examination of concrete it was found out that there were no signs of segregation as seen from Fig.(9).It may be observed that the T-50 times, which provide an indication of the relative viscosity of the SCC [9], increase with an increase in the limestone filler ratio. The increase in viscosity will help to minimize the risk of segregation during and after placement. Using of LSP in SCC reduces the dosage of superplasticizer needed to obtain similar slump flow as for concrete made with Portland cement only as seen in Table (6). 


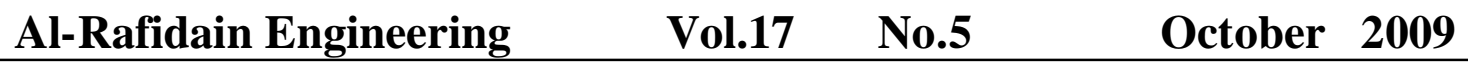

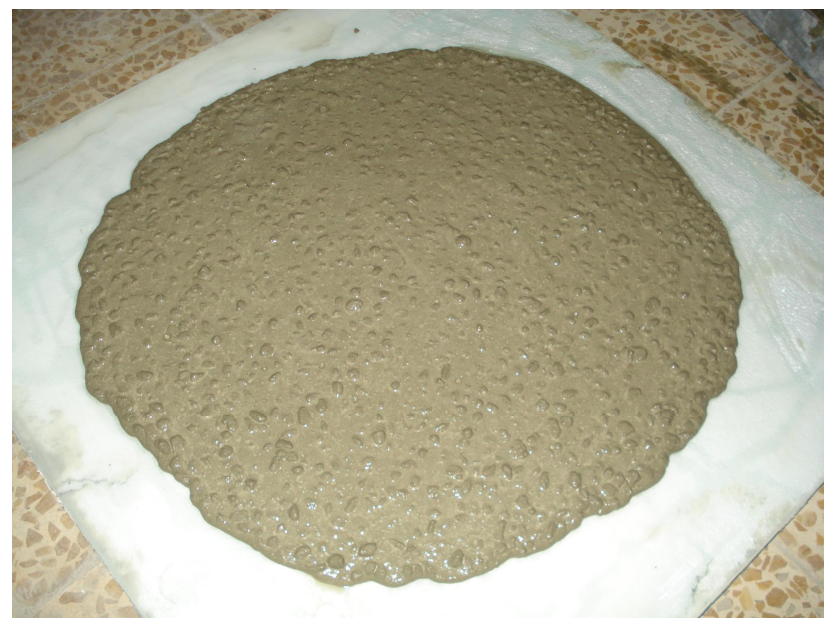

Figure (9): Measurement of slump flow (mix2)

Splitting and Flexural Tensile Strength: Table (7) presents the splitting tensile strength and flexural strength for each mix. It can be seen that the tensile and flexural strength decreases as limestone powder ratio is increased and the largest value of strength is for mix 2 which had $20 \%$ of limestone powder as replacement of O.P.C with respect to mix 3 and mix4. Figures (10) and (11) show the relation between splitting strength and percentage increase in LSP ratios and the percentage decrease of splitting strength with respect to mix1 at an increasing LSP ratio.

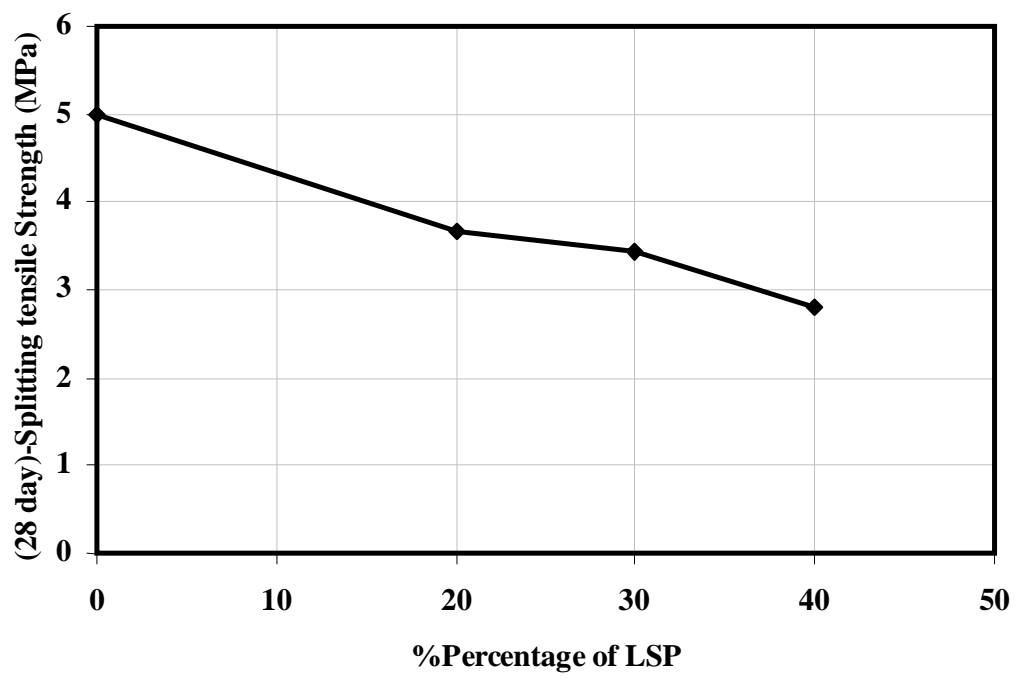

Figure (10): Relation between Percentage of LSP and splitting strength at 28 day 


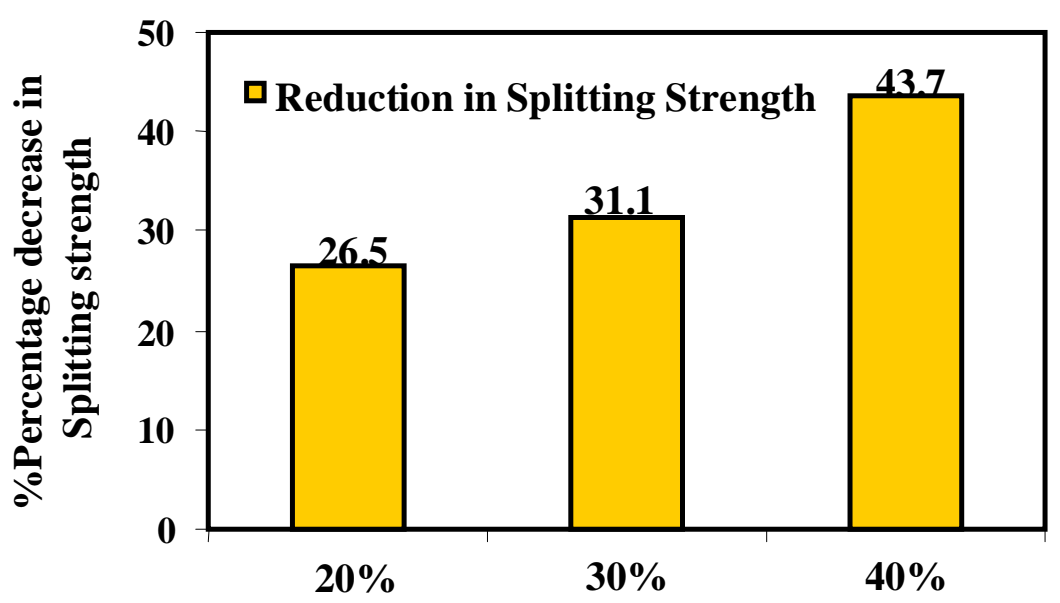

Figure (11): \% Percentage reduction in Splitting Strength with respect to mix1 with LSP increase

All specimens showed a linear mode of fracture and the same relief (surface shape) on the fractured faces. Fig. (12) Shows the specimens after failure and surface shape of the fractured faces of concrete cylinders, a uniform distribution of aggregates over the full cross section can be seen.

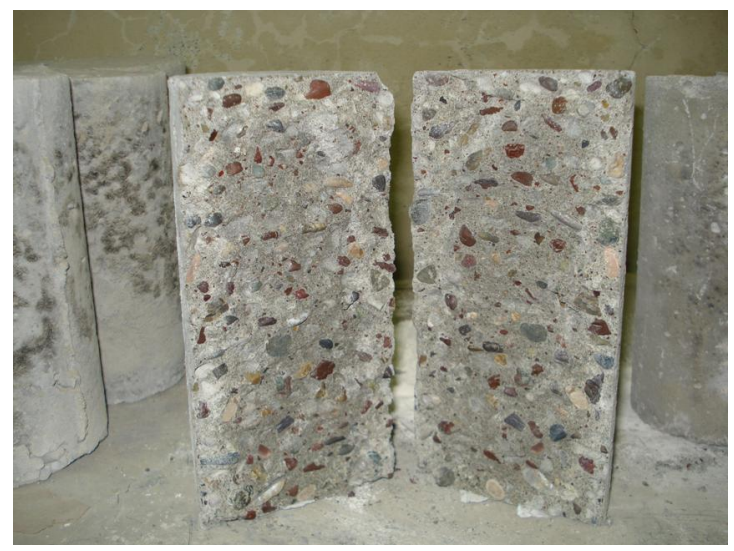

Figure (12): Linear Failure of cylinder

Figures (13) \& (14) show the relation between flexural strength (modulus of rupture) and percentage increase in LSP ratios. 


$\begin{array}{lllll}\text { Al-Rafidain Engineering } & \text { Vol.17 } & \text { No.5 } & \text { October } & 2009\end{array}$

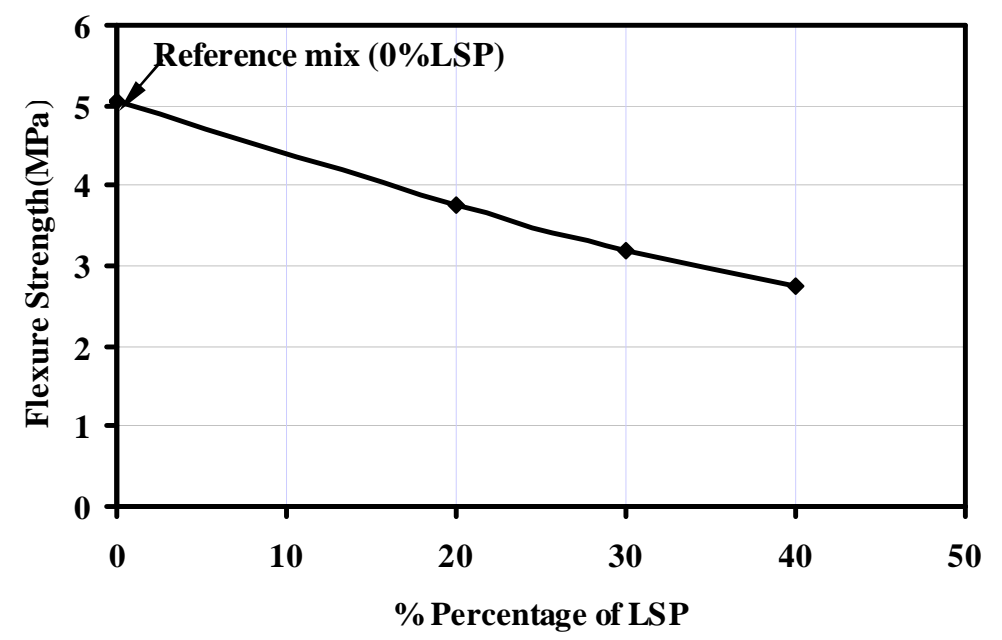

Figure (13): Relation between Percentage of LSP and Flexural Strength at 28 days

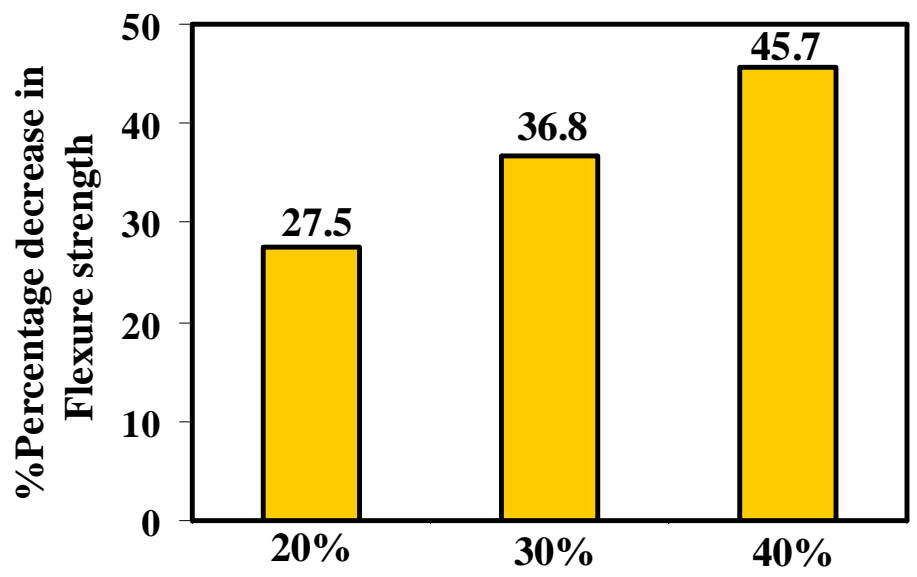

Figure (14): \%Percentage drop in Flexural Strength with respect to mix1 with Increasing LSP ratio

\section{Comparison between the addition and the replacement of limestone powder to} the SCC:

Table (8) shows the constituents materials comprising the same ratios of Cement, Sand, Gravel and water/powder as used previously. The sole variable in these mixes was the way of adding the limestone filler. In mixes 2,3, the limestone filler was added as percentage replacement of cement; in the mixes 4,5 the same percentage of limestone filler $(20,30 \%)$ is added to the cement in order to see the difference between the replacement and addition of limestone powder. 
Al-Luhybi : The Effect Of A Variable Percentage Of Limestone Filler On Some

Table (8): Proportions of the concrete mixtures

\begin{tabular}{|c|c|c|c|c|c|c|c|c|c|c|}
\hline \multirow{2}{*}{$\begin{array}{l}\text { Mix } \\
\text { No. }\end{array}$} & \multirow{2}{*}{$\begin{array}{c}\text { Water } \\
\text { Content } \\
\mathrm{kg} / \mathrm{m}^{3}\end{array}$} & \multirow{2}{*}{$\begin{array}{c}\text { Cement } \\
\text { Content } \\
\mathrm{kg} / \mathrm{m}^{3}\end{array}$} & \multicolumn{2}{|c|}{$\begin{array}{c}\text { Limestone } \\
\text { filler }\end{array}$} & \multirow{2}{*}{$\begin{array}{c}\text { Total } \\
\text { cementitious } \\
\text { material }\end{array}$} & \multirow{2}{*}{$\begin{array}{l}\text { Fine } \\
\text { agg. } \\
\mathrm{kg} / \mathrm{m}^{3}\end{array}$} & \multirow{2}{*}{$\begin{array}{c}\text { Coarse } \\
\text { agg. } \\
\mathrm{kg} / \mathrm{m}^{3}\end{array}$} & \multirow{2}{*}{$\begin{array}{c}\text { SP* } \\
\%\end{array}$} & \multirow{2}{*}{$\begin{array}{l}\text { T50 } \\
\text { (sec) }\end{array}$} & \multirow{2}{*}{$\begin{array}{l}\text { Dnsity } \\
\mathrm{kg} / \mathrm{m}^{3}\end{array}$} \\
\hline & & & $\mathrm{kg} / \mathrm{m}^{3}$ & $\%$ & & & & & & \\
\hline \multicolumn{11}{|c|}{ No Filler } \\
\hline Mix1 & 149 & 450 & $\mathbf{0}$ & $\mathbf{0}$ & 450 & 756 & 743 & 1.75 & 3.3 & 2106 \\
\hline Ratio & $\mathbf{0 . 3 3}$ & & & & 1 & 1.68 & 1.65 & & & \\
\hline \multicolumn{11}{|c|}{ Limestone Filler as a replacement } \\
\hline Mix2 & 149 & 360 & 90 & 20 & 450 & 756 & 743 & 1.6 & 3.38 & 2105 \\
\hline Mix3 & 149 & 315 & 135 & 30 & 450 & 756 & 743 & 1.625 & 3.67 & 2105 \\
\hline Ratio & 0.33 & & & & 1 & 1.68 & 1.65 & & & \\
\hline \multicolumn{11}{|c|}{ Limestone Filler as an addition } \\
\hline Mix4 & 178 & 450 & 90 & 20 & 540 & 907 & 891 & 1.72 & 3.25 & 2525 \\
\hline Mix5 & 178 & 450 & 135 & 30 & 585 & 983 & 965 & 1.74 & 2.68 & 2721 \\
\hline Ratio & 0.33 & & & & 1 & 1.68 & 1.65 & & & \\
\hline
\end{tabular}

*SP: Superplasticizer

From the results of table (8) the quantity of superplasticizer (SP) needed by those mixes to attain a flow equal to $650 \pm 15 \mathrm{~mm}$ was larger than the quantity used by mixes 2,3 because the filler content is larger and the $\mathrm{W} /(\mathrm{C}+\mathrm{LSP})$ was kept constant at 0.33 . Also it can be noticed that with the filler mixes the time needed to reach T50 was less than with respect to mixes without the filler. The mixes that had the filler as a replacement of cement are more fluid, due to increase the fine materials.

After testing the specimens, the results were clarified in Table (9). The table shows the density, compressive strength and splitting strength of these mixes. It can be noticed that the density of these mixes in the fresh and hardened state is greater than that of mixes with no filler or when the filler is used as a replacement to cement and the compressive strength increased with the time similar to conventional concrete without filler.

Table (9): Mechanical Properties of Mixes

\begin{tabular}{|l|c|c|c|c|c|}
\hline \multicolumn{1}{|c|}{ Mix } & Mix1(0\%) & Mix2(20\%) & Mix3(30\%) & Mix4(20\%) & Mix5(30\%) \\
\cline { 3 - 7 } & & $\begin{array}{c}\text { Limestone Filler as a } \\
\text { replacement }\end{array}$ & \multicolumn{2}{|c|}{$\begin{array}{c}\text { Limestone Filler as an } \\
\text { addition }\end{array}$} \\
\hline Densitykg/m at fresh state & & 2385 & 2381 & 2430 & 2438 \\
\hline Density kg/m at hardened state & 2430 & 2428 & 2425 & 2448 & 2450 \\
\hline Compressive Strength(MPa) at 3days & 26.2 & 18.2 & 16.5 & 17.1 & 15.2 \\
\hline Compressive Strength(MPa) at 7days & 36.65 & 29.4 & 25.35 & 29.3 & 24.6 \\
\hline Compressive Strength(MPa) at 28days & 44.6 & 40.7 & 30.4 & 39.8 & 27.6 \\
\hline Compressive Strength(MPa) at 56days & 56.4 & 53.3 & 38 & 52.9 & 37 \\
\hline Splitting Strength(MPa) at 28days & 4.995 & 3.667 & 3.43 & 3.78 & 2.96 \\
\hline
\end{tabular}




\section{$\begin{array}{llll}\text { Al-Rafidain Engineering } & \text { Vol.17 } & \text { No.5 } & \text { October } 2009\end{array}$}

Figure (15) shows the relationship between compressive strength and age for mixes containing 20,30\% limestone filler as cement replacement and mixes containing 20,30\% limestone filler as an additive. It can be seen that the compressive strength of mixes having $20 \%$ of limestone filler has rather similar values. A similar conclusion applies for mixes having $30 \%$ of limestone filler. This means that the use of limestone filler as a replacement or an additive material has no effect on the compressive strength except for the fact that using the limestone filler as an additive is not economical because more Plasticizer material is needed although it gives the mix more fluiditv. as fine material leads to increasing fluiditv of SCC.

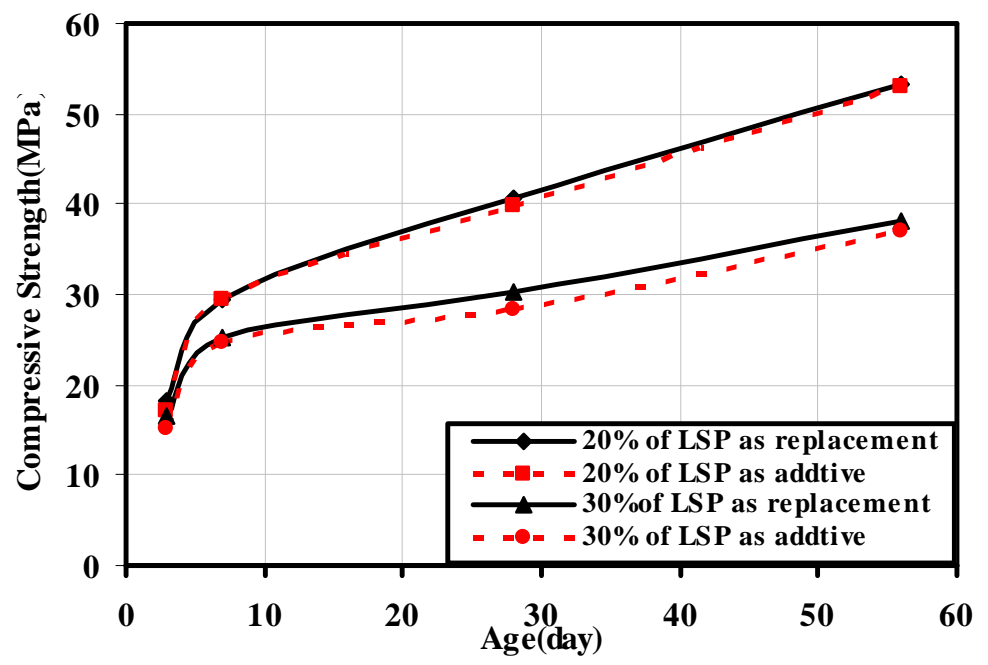

Figure (15): Relationship between Compressive Strength and age for mixes containing $(20,30 \%)$ of limestone filler as cement replacement and mixes containing $(20,30 \%)$ of limestone filler as an additive

Table (9) presents the splitting tensile strengths for each mix. It can be seen that the tensile strength for mixes containing the filler as an additive material decreased as the limestone powder ratio increased. Figure 16 shows the percentage decrease of splitting strength with respect to mix1(which had no filler) at an increasing LSP ratio. Approximately, the splitting tensile strength is about $10 \%$ of the compressive strength.

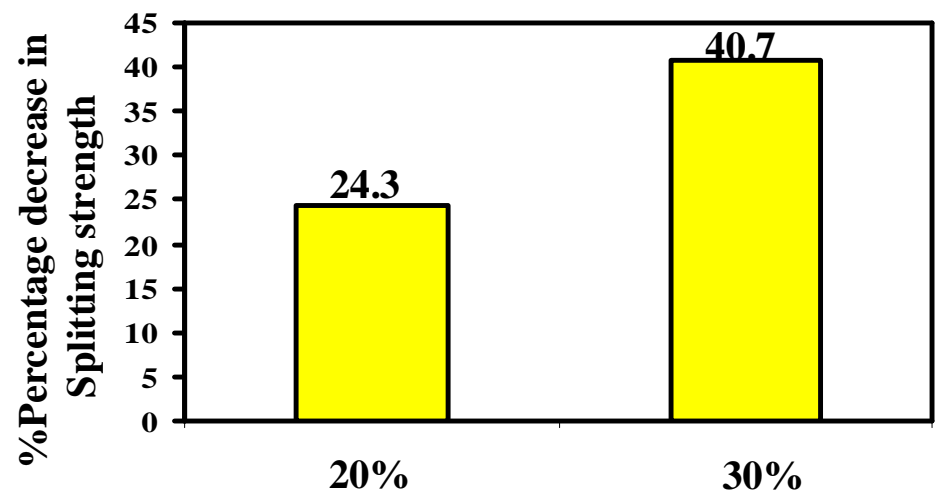

Figure (16): \% Percentage drop in Splitting Strength with respect to mix1 as Increasing $\mathrm{LSP}$ ratio 
Al-Luhybi : The Effect Of A Variable Percentage Of Limestone Filler On Some

\section{Conclusions}

1. The use of limestone filler helps successfully in producing SCC, but increasing the percentage of limestone filler does not necessarily lead to increasing mechanical properties.

2. Increasing the limestone ratio as replacement of O.P.C leads to a decrease in compressive, splitting, flexural strength.

3. Using the limestone filler as replacement of cement is more economical because the use of LSP in SCC reduces the dosage of superplasticizer needed to obtain similar slump flow as for concrete made with Portland cement only.

4. Using the limestone filler as an additive material needs greater amount of plasticizer with respect to using limestone filler as replacement of cement, but it gives more fluidity for SCC.

\section{References}

1. Khayat, Hu and Monty, proceedings first international RILEM Symposiom, SCC, Stockholm 1999.

2.Okamura, H, "Self-compacting High-Performance concrete", Concrete International, 1997, pp.50-54.

3.Ozawa, K., "Development of high performance concrete based on the durability design of concrete stractures", EASEC-2, Vol. 1, 1989, pp. 445-450.

$$
\text { 4. المو اصفة القياسية العر اقية رقم (5) لسنة } 1985 \text { (السمنت البورتلاندي). }
$$

5. B.S. 882-1992, "British Standard Specification for Aggregate from Natural Sources for Concrete", 1992.

6. Ashok, H., "Mix Design and Testing of Self-Consolidating Concrete Using Florida Materials", Final Report Submitted to the Florida Department of Transportation (Contract No. BD503), December, 2004.

7.EFNARC,"The European Guidelines for Self-Compacting Concrete Specification, Production and Use", (www.efnarc.org), May, 2005, pp. 1-68.

8. EFNARC, "Specifications and Guidelines for Self-Compacting Concrete", EFNARC, UK (www.efnarc.org), February 2002, pp.1-32.

9. ASTM C192-1995," Standard Practice for Making and Curing Concrete Test Specimens in the Laboratory", Annual Book of ASTM Standards.

10. ASTM C39-1994,"'Standard Test Method for Splitting Tensile Strength of Cylindrical Concrete Specimens", Annual Book of ASTM Standards. 